\title{
Cobalt(II) Hematoporphyrin IX Immobilized in a Cellulose Acetate Niobium(V) Oxide Composite Membrane: Preparation and Oxygen Reduction Study
}

\author{
Yoshitaka Gushikem*, and Elvio A. Campos \\ Instituto de Química, Unicamp, C.P. 6154, 13083-970 Campinas - SP, Brasil
}

November 27, 1997

\begin{abstract}
A Hematoporfirina IX [ácido (8,13,-bis(1-hidroxietil)-3,7,12,17-tetrametil-21-H-porfirina2,18-dipropionico)] foi absorvida na superfície da membrana composta orgânica/inorgânica $\mathrm{Cel} / \mathrm{Nb}_{2} \mathrm{O}_{5}$. A porfirina é fortemente aderida à superfície do $\mathrm{Nb}_{2} \mathrm{O}_{5}$ pela interação com o grupo carboxílico - $\mathrm{COOH}$ da porfirina e formação da ligação - COO-Nb. A metalação do anel porfirínico é feita mergulhando-se a membrana na solução de Co(II) por algumas horas. As bandas de absorção eletrônica Q indicaram a mudança de simetria de $\mathrm{D}_{2 \mathrm{~h}}$ para $\mathrm{D}_{4 \mathrm{~h}}$ pela metalação do anel porfirínico. A análise química demonstrou que a metalação ocorreu com rendimento de práticamente $100 \%$. O oxigênio foi reduzido na superfície do eletrodo feito com o material a um potential de pico de -390 mV em solução de $\mathrm{KCl} 1 \mathrm{M}$ a pH 1, a uma temperatura de $298 \mathrm{~K}$ à pressão ambiente. Supõe-se que o processo de redução ocorre segundo o mecanismo de transferência de dois elétrons. Foi obtida uma resposta linear da corrente de pico catódico para concentrações do oxigenio dissolvido entre 1,5 e 15 ppm.
\end{abstract}

Hematoporphyrin IX [8,13,-bis(1-hydroxyethyl)-3,7,12,17-tetramethyl-21H-porphyrin-2,18dipropionic acid] was adsorbed on the organic-inorganic composite membrane $\mathrm{Cel} / \mathrm{Nb}_{2} \mathrm{O}_{5}$ surface. The porphyrin is strongly adhered on the $\mathrm{Nb}_{2} \mathrm{O}_{5}$ surface by reaction of the porphyrin $\mathrm{CO}_{2} \mathrm{H}$ groups with $\mathrm{Nb}_{2} \mathrm{O}_{5}$ forming the $-\mathrm{COO}-\mathrm{Nb}$ chemical bond. Metallation of the porphyrine ring was made very easily by immersing the membrane in $\mathrm{Co}$ (II) solution and allowing to rest for a few hours. The electronic absorption bands due to the $\mathrm{Q}$ bands indicated the symmetry change from $\mathrm{D}_{2 \mathrm{~h}}$ to $\mathrm{D}_{4 \mathrm{~h}}$ upon metallation of the porphyrin ring. The chemical analyses of the material confirmed that the metallation yield was practically $100 \%$. Oxygen was reduced on a electrode surface made with the material under a cathodic peak potential of $-390 \mathrm{mV}$, in $1 \mathrm{M} \mathrm{KCl}$ solution at $\mathrm{pH} 1$, temperature of $298 \mathrm{~K}$ and at ambient pressure. The oxygen reduction was proposed to occur by a two electron transfer mechanism. A linear cathodic peak current response was obtained for dissolved oxygen concentrations between 1.5 and $15 \mathrm{ppm}$.

Keywords: $C o(I I)$ hematoporphyrin IX, celullose acetate membrane, cellulose-niobium(V) oxide composite membrane, oxygen catalytic reduction

\section{Introduction}

Niobium pentoxide has been investigated with respect to its surface acid strength, ion exchange capacity, and use as specific sorbent for many metal ions ${ }^{1-3}$. Since the bulk oxide is normally obtained as a fine untractable powder with poor mechanical resistance, it has been dispersed on a surface of silica gel ${ }^{4}$. However, the mineral matrix is rigid and for some applications where molding of the material is required it is not convenient. In a recent work, the obtention and characterization of the composite membrane celulose/oxide, $\mathrm{Cel} / \mathrm{Nb}_{2} \mathrm{O}_{5}$, with high degree dispersion and homogeinity of the oxide particles was described ${ }^{5}$. The Lewis acid sites of the dispersed oxide were shown to be reasonably stable. It is known that these Lewis acid sites can immobilize an organic acid enabling the chemical species be tightly anchored to the metal oxide by the $-\mathrm{COO}-\mathrm{Nb}$ bond formation and thus, avoiding leaching from the surface as the material is immersed in a solvent ${ }^{6}$. 
In this work the immobilization procedures of hematoporhyrin IX [8,13,-bis(1-hydroxyethyl)-3,7,12,17tetramethyl-21H-porphyrin-2,28-dipropionic acid], $\mathrm{H}_{2}$ (HMP), in cellulose/niobium(V) oxide composite membrane and further metallation with cobalt (II) ion are described. The nature of the cobalt ion was firstly investigated, since it has been described that the metal is readily oxidized in air $^{7}$. A membrane of the resulting material was adhered on a platinum electrode surface and the study of electrocatalytic reduction of dissolved oxygen by the electroactive species is also reported in this work.

\section{Experimental}

\section{Preparations}

About $10 \mathrm{~g}$ of cellulose acetate (Aldrich, 2.5 degree of acetylation) was added to a mixture containing $31 \mathrm{~mL}$ of glacial acetic acid and $71 \mathrm{~mL}$ of acetone. The mixture was vigorously stirred for $2 \mathrm{~h}$ and allowed to rest for $24 \mathrm{~h}$ after which a viscous syroup was formed. Freshly sublimed $\mathrm{NbCl}_{5}(2 \mathrm{~g})$ was added into $10 \mathrm{~g}$ of the celullose acetate syrup and the mixture stirred under a nitrogen atmosphere until complete dissolution of the metal halide which occured with evolution of gaseous $\mathrm{HCl}$. The reaction flask was purged with nitrogen until almost all entrapped $\mathrm{HCl}$ was eliminated and could not be detected in the syrup. The test for $\mathrm{Cl}^{-}$was carried out by adding $\mathrm{AgNO}_{3}$ solution into a sample taken from the syrup and diluted with $0.1 \mathrm{M} \mathrm{HNO}_{3}$ solution. This viscous syroup is named as solution A.

Films of the composite membranes were prepared by spreading the solution A over a glass plate and the thickness was controlled to $200 \mu \mathrm{m}$ by using a spacer. The film was allowed to rest for $2 \mathrm{~h}$ open to room atmosphere in order to evaporate most of the solvents. To promote the metal hydrolysis, the glass plate was immersed in distilled water and the film was detached from the surface.

About $0.054 \mathrm{~g}\left(10^{-4} \mathrm{~mol}\right)$ of $\mathrm{H}_{2}(\mathrm{HMP})$ (Sigma) was dissolved in $50 \mathrm{~mL}$ of ethanol/water solution $(9: 1 \mathrm{v} / \mathrm{v})$. The membrane of $\mathrm{Cel} / \mathrm{Nb}_{2} \mathrm{O}_{5}$ with approximately $3 \mathrm{~cm}^{2}$ was immersed in this solution and after $4 \mathrm{~h}$ it was washed and stored in bidistilled water protected against light. To metallate this membrane, it was immersed in $0.1 \mathrm{M} \mathrm{CoCl}_{2}$ aqueous solution for $5 \mathrm{~h}$ with occasional shaking. The membrane was washed with water and dried at $333 \mathrm{~K}$.

\section{Chemical analyses}

The quantity of incorporated metal oxide in the matrix was determined by igniting the material to $1173 \mathrm{~K}$ for $1 \mathrm{~h}$ and weighing the residue as $\mathrm{Nb}_{2} \mathrm{O}_{5}$.

In order to determine the amount of metallated hematoporphyrin incorporated in $\mathrm{Cel} / \mathrm{Nb}_{2} \mathrm{O}_{5}, 0.1 \mathrm{~g}$ of the membrane was immersed in concentrated sulphuric acid and gently heated until dissolution. To analyze the metal, the solution was carefully diluted to $100 \mathrm{~mL}$ and neutral- ized with sodium bicarbonate aqueous solution $(10 \% \mathrm{~m} / \mathrm{v})$ and measured on a atomic absorption spectrometer. The amount of porphyrin molecule was determined by nitrogen determination using the Kjeldhal method. The results of the elemental analyses can be summarized as follow: $\mathrm{N}=$ $152 \pm 3 \mu \mathrm{mol} \mathrm{g}{ }^{-1}$ (corresponding to $38 \mu \mathrm{mol} \mathrm{g}{ }^{-1}$ of $\mathrm{He}$ matoporhyrin); $\mathrm{Co}=39.5 \pm 0.8 \mu \mathrm{mol} \mathrm{g}{ }^{-1}$. The results indicate that porphyrin ring metallation was $100 \%$.

\section{Spectra measurements}

The UV-Visible spectra of $\mathrm{Cel} / \mathrm{Nb}_{2} \mathrm{O}_{5} / \mathrm{HMP}$ thin films, metallated and unmetallated, were obtained on a Beckman DU 640 spectrophotometer.

Electron spin resonance spectrum of the sample was obtained at $77 \mathrm{~K}$, frequency modulated at $9.45 \mathrm{gHz}$. The equipment used was a Bruker 106 electron spin resonance spectrometer.

\section{Electrochemical measurements}

The electrode, consisting of a glass tube with a platinum disk fused at one end was immersed in the solution $\mathrm{A}$, in which $\mathrm{LiCl}$ was previously dissolved $(0.1 \mathrm{~g}$ per gram of solution A). The objective of adding this electrolyte in solution A was to obtain a porous membrane adhered on the platinum surface ${ }^{5}$. The solvent was evaporated in air and the film adhered electrode was washed with water. Adsorption of the porphyrin on the film was made by dipping the electrode in $10^{-4} \mathrm{M} \mathrm{H}_{2}$ (HMP) ethanol/water $(9: 1 \mathrm{v} / \mathrm{v})$ solution, as described above. The metallation procedure was the same as that described above. The electrode was stored in a $1 \mathrm{M} \mathrm{KCl}$ solution.

\section{Cyclic voltammetry study}

The cyclic voltammetry studies were carried out in a cell with three electrodes: the saturated calomel electrode was the reference, the counter electrode was a platinum wire and the electrode prepared as above was the working electrode. The measurements were carried out on a PAR 273 A model instrument.

\section{Dissolved oxygen}

To measure the electrode response to dissolved oxygen, the cell was filled with $1 \mathrm{M} \mathrm{KCl}$ solution at $\mathrm{pH} 1$ and saturated with pure oxygen at $298 \pm 0.5 \mathrm{~K}$. To change the concentration of the oxygen, argon was passed through the solution and the content of oxygen in each case determined by the Winkler method ${ }^{8}$.

\section{Results and discussion}

Organic compounds having carboxylate functional groups are immobilized on niobium oxide surface by a $-\mathrm{COO}-\mathrm{Nb}$ bond formation ${ }^{6}$. Figure 1 illustrates the HMP and $\mathrm{Co}(\mathrm{HMP})$ immobilized on $\mathrm{Cel} / \mathrm{Nb}_{2} \mathrm{O}_{5}$. The $\mathrm{pKa}$ of the 

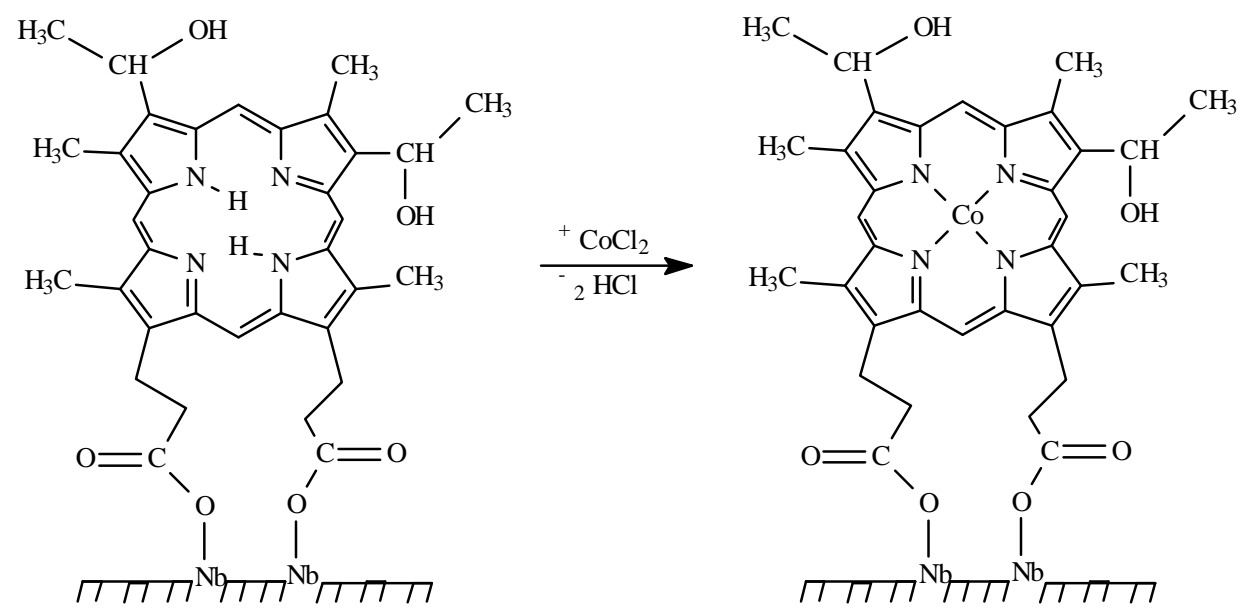

Figure 1. Metallation of the Hematoporphrin IX immobilized on $\mathrm{Cel} / \mathrm{Nb}_{2} \mathrm{O}_{5}$ with $\mathrm{Co}(\mathrm{II})$. The symmetry of the ring changes from $\mathrm{D}_{2} \mathrm{~h}$ to $\mathrm{D}_{4} \mathrm{~h}$ on metallation.

protonated imino nitrogens of the porphyrin ring are 3.0 and 6.1 in water $^{9}$ and thus, insertion of the metal ion in the porphyrin ring is not difficult. The absorption spectra are shown in Fig. 2. The $\mathrm{H}_{2}(\mathrm{HMP})$ absorbs intensely at $\lambda_{\max }$ $350 \mathrm{~nm}$ (Soret band, corresponding to the strongly allowed transition from $\mathrm{a}_{1 \mathrm{u}}$ to $\mathrm{e}_{\mathrm{g}}$ energy levels) and more weakly between 470 and $630 \mathrm{~nm}(\mathrm{Q}$ bands, correponding to the transition from $\mathrm{a}_{2 \mathrm{u}}$ to $\mathrm{e}_{\mathrm{g}}$ energy levels ${ }^{10}$ ) (Fig. 2A). Upon metallation of the porphyrin ring system, a change in the spectrum (Fig. 2B) is observed. For $\mathrm{H}_{2}$ (HMP) the $\mathrm{Q}$ bands $\left(\lambda_{\max }\right.$ in $\mathrm{nm}$ ) are observed at 470, 530, 570 and 620 and, for $\mathrm{Co}$ (HMP) at 520 and 560. The decrease in the number of bands is assigned to the symmetry increase of the metal-

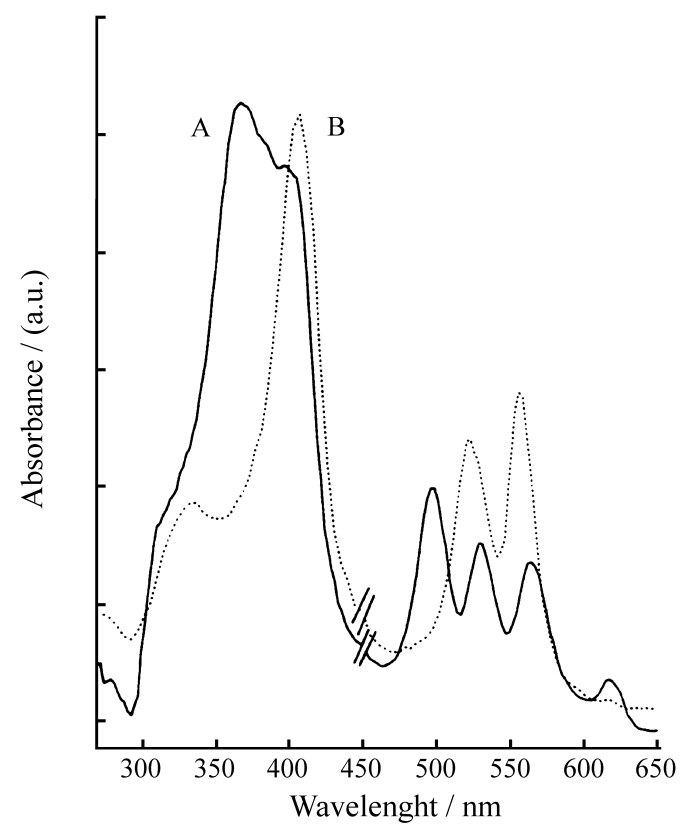

Figure 2. UV-Visible spectra of the membranes: A) $\mathrm{Cel} / \mathrm{Nb}_{2} \mathrm{O}_{5} / \mathrm{HMP}, \mathrm{B}$ ) $\mathrm{Cel} / \mathrm{Nb}_{2} \mathrm{O}_{5} / \mathrm{Co}(\mathrm{HMP})$. Between 450 and $650 \mathrm{~nm}$ the spectra were expanded since the intesities of $\mathrm{Q}$ bands are very weak in relation to the Soret bands. lated complex relative to the free immobilized porhyrin (Fig. 1) i.e., the symmetry changed from $\mathrm{D}_{2 \mathrm{~h}}$ in $\mathrm{Cel} / \mathrm{Nb}_{2} \mathrm{O}_{5} / \mathrm{HMP}$ to $\mathrm{D}_{4 \mathrm{~h}}$ in $\mathrm{Cel} / \mathrm{Nb}_{2} \mathrm{O}_{5} / \mathrm{Co}$ (HMP). As the chemical analyses showed above, almost all porhyrin rings were metallated. The Soret band is broadened in the unmetallated ring due to dimerization of the porphyrin rings and it becomes narrower upon metal incorporation?

\section{ESR spectrum}

It has been reported that the complex of cobalt (II) with hematoporhyrin is readly oxidized in air $^{7}$. In order to certify that in the present case such oxidation can also occur, the esr spectrum of the $\mathrm{Cel} / \mathrm{Nb}_{2} \mathrm{O}_{5} / \mathrm{Co}(\mathrm{HMP})$ was obtained at $77 \mathrm{~K}$. The spectrum is shown in Fig. 3.

Under magnetic field below 3000 gauss, the g values are 2.573 and 2.315 which correspond to $\mathrm{CO}^{\mathrm{II}}$ species and the signal observed between 3200 and 3500 gauss (inserted figure in detail) is an indication of the existence of molecular oxygen from air coordinated to $\mathrm{Co}^{\mathrm{II} 11,12}$. The calculated parameters are: $\mathrm{g}_{\|}=1.973$ and $\mathrm{g}_{\perp}=2.042$; hyperfine coupling constants $\mathrm{A}_{\|}=14.24 \times 10^{-4} \mathrm{~cm}^{-1}$ and $\mathrm{A}_{\perp}=15.83$ $\mathrm{x} 10^{-4} \mathrm{~cm}^{-1}$.

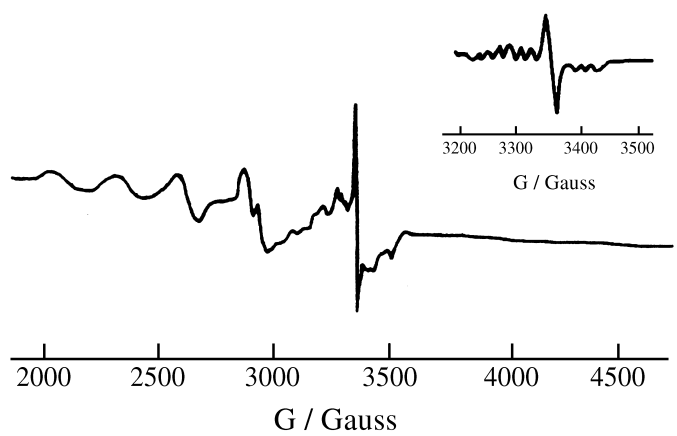

Figure 3. Electron spin resonance spectrum of $\mathrm{Cel} / \mathrm{Nb}_{2} \mathrm{O}_{5} / \mathrm{Co}(\mathrm{HMP})$ membrane at $77 \mathrm{~K}$. 


\section{Electrochemical properties}

Figure 4 shows the pulse differential voltammetry of the metallated complex between -800 and $1000 \mathrm{mV}$ under oxygen (Fig. 4A) and argon (Fig. 4B) atmospheres. Under oxygen atmosphere the anodic waves show the peak maxima of higher intensity at $-390 \mathrm{mV}$ and of a weaker peak at $-190 \mathrm{mV}$ (Fig. 4A) and, under argon atmosphere the intensity of these peaks are reversed (Fig. 4B). The observed peaks correspond to the $\mathrm{Co}^{\mathrm{I}} \rightarrow \mathrm{Co}^{\mathrm{II}}$ oxidation process of both complexes, the more negative peak being due to the oxygen axially coordinated complex species and the less negative peak to the uncoordinated complex species. Sweeping the potential to the more positive potential region, a single peak with maximum at $823 \mathrm{mV}$ due to $\mathrm{Co}^{\mathrm{II}}$ $\rightarrow \mathrm{Co}^{\mathrm{III}}$ oxidation process is observed. Reversing the sweeping direction, from the more positive to more negative potentials, similar results for $\mathrm{Co}^{\mathrm{II}} \rightarrow \mathrm{Co}^{\mathrm{I}}$ reduction process under oxygen (Fig. 4C) and argon (Fig. 4D) atmospheres are observed. The peak corresponding to $\mathrm{Co}^{\mathrm{III}} \rightarrow$ $\mathrm{Co}^{\mathrm{II}}$ process was not observed.

The catalytic reduction of dissolved oxygen is very dependent on the solution $\mathrm{pH}$ in which the measurements

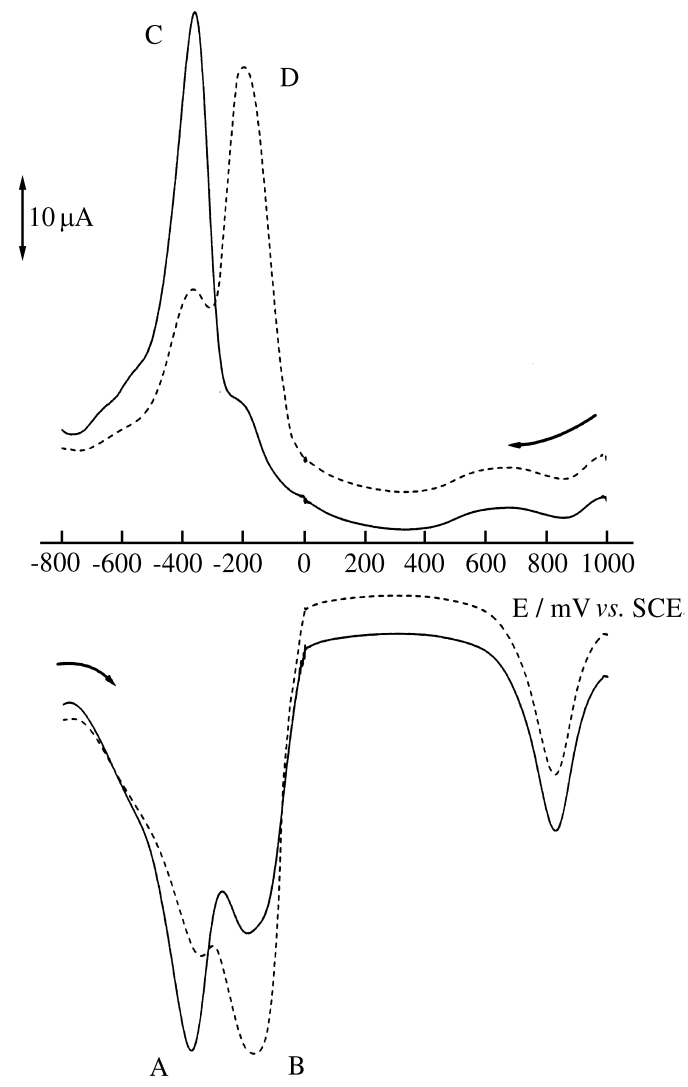

Figure 4. Differential pulse voltammetry curves of $\mathrm{Cel} / \mathrm{Nb}_{2} \mathrm{O}_{5} / \mathrm{CoHMP}$ electrode. Anodic sweeping: (A) under oxygen atmosphere, B) under argon atmosphere; cathodic sweeping: (C) under oxygen atmosphere, (D) under argon atmosphere. are carried out ${ }^{13-16}$. In the present case, the oxygen reduction at the electrode surface was studied in $1 \mathrm{M} \mathrm{KCl}$ solution and pHs between 1 and 6 at temperature of $298 \mathrm{~K}$. Figure 5 shows the plot of current peak maxima against the solution $\mathrm{pH}$. The current intensities with the maximum value at $\mathrm{pH} 1$ exponentially decreased as the $\mathrm{pH}$ of the solutions was increased up to $\mathrm{pH} 6$.

In a typical cyclic voltammetry experiment, the cyclic voltammogram curves of $\mathrm{Cel} / \mathrm{Nb}_{2} \mathrm{O}_{5} / \mathrm{Co}(\mathrm{HMP})$ in the presence of oxygen (Fig. 6A) and when the solution was purged with argon (Fig. 6B) are shown. The peak that remains at about $-450 \mathrm{mV}$ (Fig. 6B) is presumably due to the oxygen molecule coordinated to $\mathrm{Co}(\mathrm{II})^{11,12}$ which is difficult to eliminate during purging of the system with argon. Fig. 6C shows the curve obtained for the electrode made with $\mathrm{Cel} / \mathrm{Nb}_{2} \mathrm{O}_{5}$ in the presence of oxygen (blank test). In this case, a peak with small current intensity is observed at $-400 \mathrm{mV}$, the origin of which has not clear explanation. However, it disappeared on purging the electrochemical cell with argon. Anyway, the observed peak at $-390 \mathrm{mV}$ (Fig. 6A) is considerably enhanced in the presence of $\mathrm{O}_{2}$ and it is assigned to the oxygen electrocatalytic reduction at the modified electrode surface. On the Pt electrode surface under similar conditions, oxygen is reduced at nearly $-570 \mathrm{mV}^{17}$.

The stability of the electrode was tested by cycling the potential between -200 and $-500 \mathrm{mV}$ many times. Leaching of the electroactive species was not observed and the intensity of the peak current remained constant during the experiment. In another experiment, in order to test electrode response to dissolved oxygen, the electrochemical cell was alternately purged with pure argon and pure oxygen at a fixed potential of $-390 \mathrm{mV}$ and constant temperature of $298 \mathrm{~K}$ and $\mathrm{pH} 1$. Bubbling oxygen into the cell $\left(\mathrm{O}_{2}{ }^{\text {in }}\right.$, Fig. 7) or argon (Ar ${ }^{\text {in }}$, Fig. 7) the current intensities increased

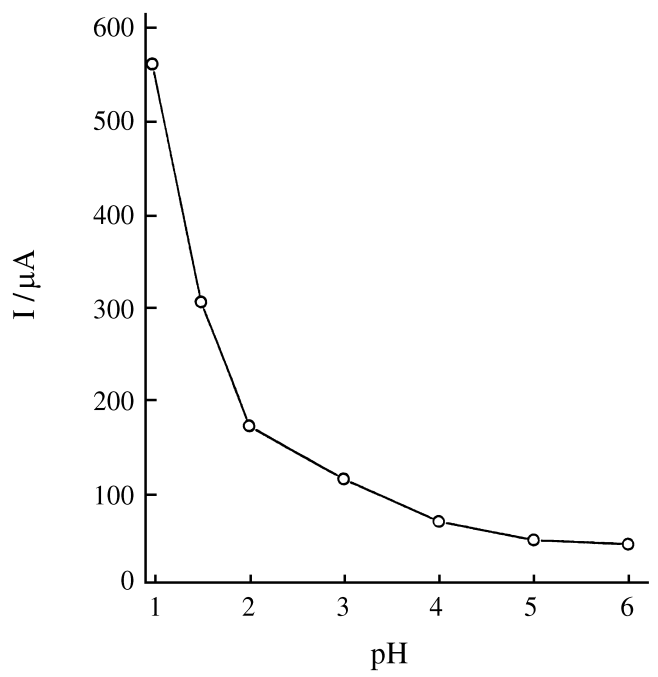

Figure 5. Electroreduction peak current intensities of $\mathrm{Cel} / \mathrm{Nb}_{2} \mathrm{O}_{5} / \mathrm{Co}$ (HMP) electrode in $1 \mathrm{M} \mathrm{KCl}$ solutions at different $\mathrm{pHs}$. 


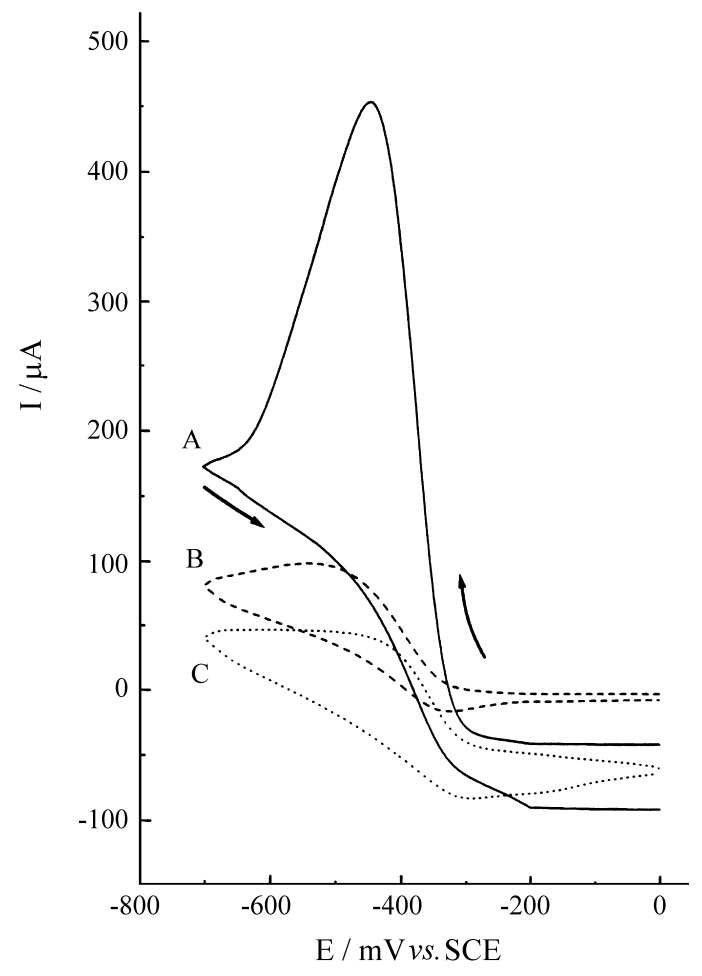

Figure 6. Cyclic voltammograms of $\mathrm{Cel} / \mathrm{Nb}_{2} \mathrm{O}_{5} / \mathrm{Co}(\mathrm{HMP})$ electrode in 1 $\mathrm{M} \mathrm{KCl}$ solution at $\mathrm{pH} 1$ and scan rate of $20 \mathrm{mV} \mathrm{s}^{-1}$ : A) in dissolved oxygen solution, B) in solution purged with argon. C) unmetallated $\mathrm{Cel} / \mathrm{Nb}_{2} \mathrm{O}_{5} / \mathrm{HMP}$ in dissolved oxygen solution measured in similar conditions.

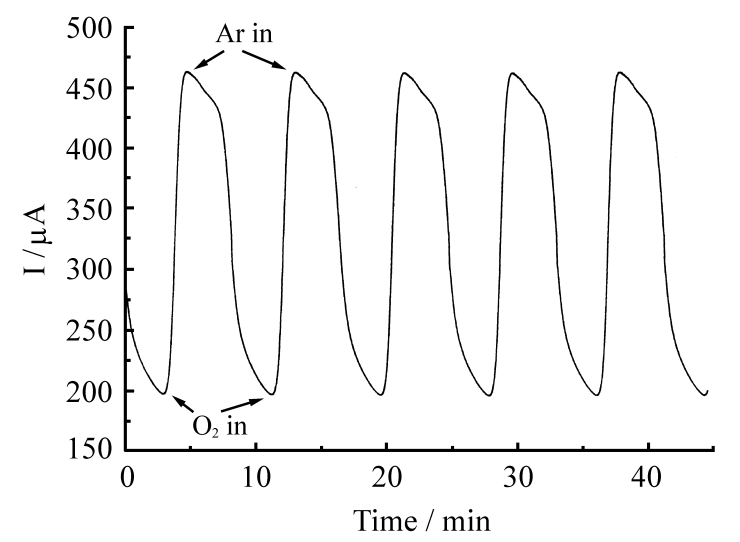

Figure 7. Cathodic peak currents in $1 \mathrm{M} \mathrm{KCl}$ solution at $\mathrm{pH} 1$ for alternated cycles in presence of oxygen $\left(\mathrm{O}_{2}{ }^{\text {in }}\right)$ and purged with argon $\left(\mathrm{Ar}^{\mathrm{in}}\right)$ measured at $-390 \mathrm{mV}$.

for $\mathrm{O}_{2}{ }^{\text {in }}$ and decreased for $\mathrm{Ar}^{\text {in }}$ alternately in five sucessive cycles, the maxima and the minima remaining practically constant. Furthermore, the electrode response towards dissolved oxygen concentrations was also tested. The experiment was carried out measuring the cathodic peak current of the cyclic voltammograms for a given dissolved oxygen concentration in the cell. Figure 8 shows the cathodic peak current intensity against dissolved oxygen concentration,

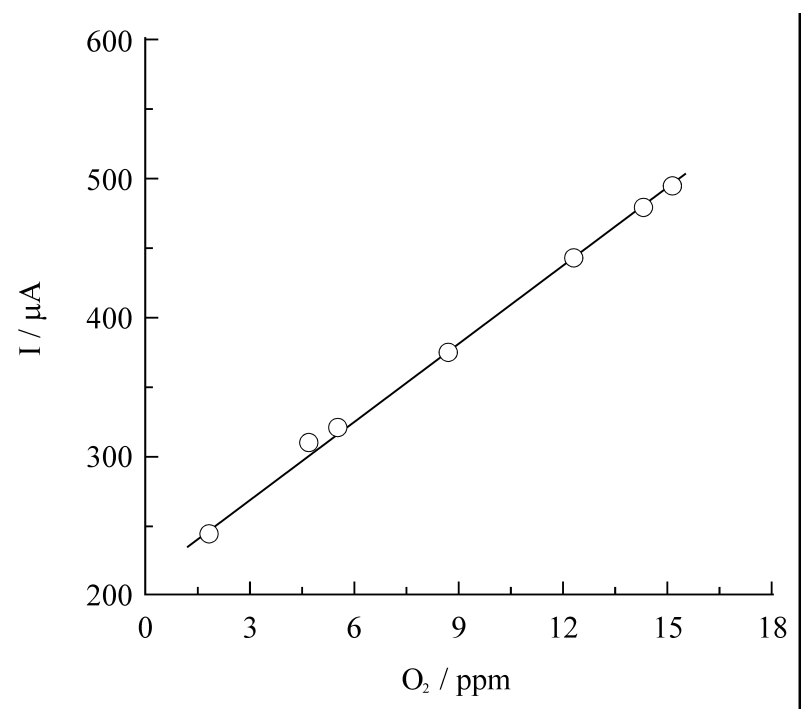

Figure 8. Cathodic peak current intensities against concentration of dissolved oxygen concentration. Experimental conditions: $298 \mathrm{~K}, 1 \mathrm{M}$ $\mathrm{KCl}$ solution at $\mathrm{pH} 1$, ambient pressure, and electrode of $\mathrm{Cel} / \mathrm{Nb}_{2} \mathrm{O}_{5} / \mathrm{Co}(\mathrm{HMP})$

where a linear correlation between 1.5 and 15 ppm was observed.

Although the untreated cellulose acetate membranes normally present high rejection coefficient for electrolytes, the efficient electrochemical process at the electrode surface-solution interface is related with the facility under which the membrane is wet when immersed in the electrolyte solution ${ }^{18}$ and also the presence of $\mathrm{Nb}_{2} \mathrm{O}_{5}$ in the matrix which increases its hydrophilic character.

The probable mechanism of oxygen reduction is that of a two electron transfer process ${ }^{13}$ as described for a similar system in an homogeneous solution, according to the the following suggested mechanism ${ }^{14,15}$ :

$$
\begin{aligned}
& {[\mathrm{Co}(\mathrm{II})]+\mathrm{O}_{2} \longrightarrow\left[\mathrm{Co}(\mathrm{II}) \mathrm{O}_{2}\right]} \\
& {\left[\mathrm{Co}(\mathrm{II}) \mathrm{O}_{2}\right]+\mathrm{e}^{-} \longrightarrow[\mathrm{Co}(\mathrm{I})] \mathrm{O}_{2}} \\
& {[\mathrm{Co}(\mathrm{I})] \mathrm{O}_{2}+2 \mathrm{H}^{+} \longrightarrow[\mathrm{Co}(\mathrm{III})]+\mathrm{H}_{2} \mathrm{O}_{2}}
\end{aligned}
$$

The electroreduction of $\mathrm{O}_{2}$ by $\mathrm{Co}$ (II) porphyrin starts with oxygen coordination to the metal ion (Eq. 1) ${ }^{19}$ followed by further electrochemical reduction at the electrode surface (Eq. 2). The transference of two electrons by cobalt(I) ion to $\mathrm{O}_{2}$ occurs at the third stage of the reaction (Eq. $3)$. As the last stage, $\mathrm{Co}$ (III) is electrochemically reduced to $\mathrm{Co}$ (II) and the cycle starts with coordenative adsorption of $\mathrm{O}_{2}$.

\section{Conclusions}

Cobalt(II) ion is quantitatively incorporated to the hematoporphyrin IX ring immobilized on the $\mathrm{Cel} / \mathrm{Nb}_{2} \mathrm{O}_{5}$ surface. The complex is not leached from the surface even at high supporting electrolyte solution since it is immobilized 
into the matrix surface by the $-\mathrm{COO}-\mathrm{Nb}$ chemical bond. The cobalt-porphyrin acts as the active site oxygen reduction, presumably by a two-electron transfer mechanism.

Considering the relatively good chemical stability, the linear response of the peak current against the dissolved oxygen concentration at atmospheric pressure and ambient temperature, this metalloporphyrin-modified electrode system appears to be potentially useful for developing a new oxygen sensor.

\section{Acknowledgments}

Y.G. is indebted to FAPESP for finacial support and E.A.C, to CAPES for a fellowship.

\section{References}

1. Inoue, Y.; Yamazaki, H.; Kimura, Y. Bull. Chem. Soc. Jpn. 1985, 58, 2481.

2. Yamazaki, H.; Inoue, Y.; Okada, K.; Morita, K. Bull. Chem. Soc. Jpn. 1985 58, 2955.

3. Yamazaki, H.; Inoue, Y.; Sahara, S. Bull. Chem. Soc. Jpn. 1993, 66, 1127.

4. Denofre, S.; Gushikem, Y.; de Castro, S.C.; Kawano, Y. J. Chem. Soc. Faraday Trans. 1993, 89, 1057.

5. Campos, E.A.; Gushikem, Y. J. Colloid Interface Sci. 1997, 193, 121.

6. Denofre, S.; Gushikem, Y.; Davanzo, C.U. Eur. J. Solid State Inorg. Chem. 1991, 28, 1295.

7. Yatsmirskii, K.B.; Yakubovichi, T.N.; Bratushko, Y.I.; Kotlyar, S.S.; Yanishpol' skii, V.V.; Tertykh,
V.A. Dokl. Akad. Nauk 1985, 280, 83 translated to English.

8. Van, J.C. In Chemical Analysis of Inorganic Constituents of Water, Robinson, J.W., Ed.; CRC Press Inc, Boca Raton, 1977, 191.

9. Pottier, R.H.; Kennedy, J.C.; Chow, Y.F.A.; Cheung, F. Can. J. Spectrosc. 1988, 33, 57.

10. Corwin, A.H.; Chivvis, A.B.; Poor, Whitten, D.G.; Baker, E.W. J. Am. Chem. Soc. 1968, 90, 657.

11. de Bolfo, J.A.; Smith, T.D.; Boas, J.F.; Pilbrow, J.R. J.Chem. Soc. Faraday II 1976, 481.

12. de Bolfo, J.A.; Smith, T.D.; Boas, J.F.; Pilbrow, J.R. J. Chem. Soc. Dalton 1976, 1495.

13. Yeager, E. J. Mol. Catal. 1986, 38, 5.

14. Yuasa, M.; Nagaiwa, T.; Kato, M.; Sekine, I.; Hayashi, S. J. Electrochem. Soc. 1995, 142, 2612.

15. D'Souza, F.; Deviprasad, R.G.; Hsieh, Y. J. Electroanal. Chem. 1996, 411, 167.

16. Gouérec, P.; Bilou, A.; Contamin, O.; Scarbeck, G.; Savy, M.; Barbe, J.M.; Guilard, R. J. Electroanal. Chem. 1995, 398, 67.

17. Kuwana, T.; Fujihira, M.; Sunakawa, K.; Osa, T. J. Electroanal. Chem. 1977, 88, 299.

18. Rodrigues Filho, U.P.; Gushikem, Y.; Gonçalves, M.C.; Cachichi, R.C.; de Castro, S.C. Chem. Mater. 1996, 8, 1375.

19. An alternative mechanism suggests that the reaction starts with the electroreduction, $\mathrm{Co}(\mathrm{II}) \rightarrow \mathrm{Co}(\mathrm{I})$, and the molecular oxygen is coordenatively adsoberd on $[\mathrm{Co}(\mathrm{I})]$ species. 